Meta

Journal des tradlucteurs

Translators' Journal

\title{
Introductory Paper: Text Linguistics, Text Types and Prototypes
}

\section{Hildegund Bühler}

Volume 33, numéro 4, décembre 1988

Symposium AILA 1987, Sydney

URI : https://id.erudit.org/iderudit/002175ar

DOI : https://doi.org/10.7202/002175ar

Aller au sommaire du numéro

Éditeur(s)

Les Presses de l'Université de Montréal

ISSN

0026-0452 (imprimé)

1492-1421 (numérique)

Découvrir la revue

Citer cet article

Bühler, H. (1988). Introductory Paper: Text Linguistics, Text Types and Prototypes. Meta, 33(4), 465-467. https://doi.org/10.7202/002175ar d'utilisation que vous pouvez consulter en ligne.

https://apropos.erudit.org/fr/usagers/politique-dutilisation/ 


\section{INTRODUCTORY PAPER : TEXT LINGUISTICS, TEXT TYPES AND PROTOTYPES}

The AILA Scientific Commission on Translating and Interpreting has been active in the field of translation and interpretation research and didactics since AILA 1978 in Montreal. The present convenors are Reiner Arntz, University of Hildesheim, FRG, Hildegund Bühler, University of Vienna, Austria, and André Clas, University of Montreal, Canada.

During a meeting of the AILA Commission on Interpreting and Translating at AILA 1984 in Brussels commission member Albrecht Neubert from the Karl-MarxUniversity, Leipzig, suggested Translation Prototypes as the topic for one of the symposia to be organized by the Commission. It was decided to choose this important topic for a symposium on the occasion of AILA 1987 in Sydney. For while translation scholars have suggested a practicable typology of source language texts, no attempt has as yet been made to develop a coherent target-language text typology, a typology of translation and translating.

I will therefore in my introductory paper venture to develop some of the ideas on Text Types and Prototypes put forth by A. Neubert in his recent book (Neubert 1985) as well as by other authors in the field of text linguistics and translation studies.

In their work Introduction to Textlinguistics (1986, for the following discussion cf. chapter 1) R.-A. de Beaugrande and W.U. Dressler suggest seven standards of textuality : the text-centred standards of cohesion and coherence, cohesion resting upon grammatical dependencies and coherence concerning the ways in which the components of the textual world, i.e. the configuration of concepts and relations which underlie the surface text, are mutually accessible and relevant. More important in the context of translation studies are the user-centred notions which are brought to bear on the activity of textual communication at large both by producers and by receivers. These standards are called intentionality, concerning the text producer's attitudes, acceptability, concerning the text receiver's attitudes, informativity, concerning the extent to which the occurrences of the presented text are expected vs. unexpected or known vs. unknown, and situationality, concerning the factors which make a text relevant to the situation of occurrence.

The seventh standard of textuality suggested by de Beaugrande and Dressler is the standard of intertextuality, concerning the factors which make the utilisation of one text dependent upon knowledge of one or more previously encountered texts. Intertextuality is, in a general fashion, responsible for the evolution of text types as classes of texts with typical patterns of characteristics.

A text type is a set of heuristics for producing, predicting, and processing textual occurrences and hence acts as a predominant determiner of efficiency, effectiveness, and appropriateness. The efficiency of a text depends on its use in communicating with a minimum expenditure of effort by the participants. The effectiveness of a text depends on its leaving a strong impression and creating favourable conditions for attaining a goal. The appropriateness of a text is the agreement between its setting and the ways in 
which the standards of textuality are upheld. (Cf. Beaugrande and Dressler 1986:11, 186 ; Neubert $1985: 159$, note 67 .)

In his book (Neubert 1985, for the following discussion cf. 2.3.1 Text Types, 2.3.2 Prototypes, quotations in italics) A. Neubert in quoting Beaugrande and Dressler furthermore holds that significant variations of intertextuality provide the empirical basis of a text typology, and he assumes that translators are extremely sensitive to text-typological considerations because their task makes it imperative for them not only to become cognizant of the "cues and symbolic conventions" typical of the L1 text, but also to decide upon the ways and means of "sustaining the involvement" of their L2 audience. In other words, translators have to meet the challenge of rendering an L1 text, which is couched in the typical communicative activities of $L 1$ users, into an L2 text where other "symbolic conventions" determine the communicative practice of "participants to retrieve relevant items of information". Translation turns out to be an exercise in intertextuality across languages. (For the above of. Neubert 1985 : 121.)

Neubert also states that while translations as in the case of all other L2 texts conform to the text-typological demands of the $L 2$ communicative community and its respective subdivisions, it is not mandatory that those "text-typological demands" would have to be enforced with equal rigidity for all texts, or, rather, all types of texts. Translations "move" within the bounds of a more or less clearly defined L2 text type (cf. Neubert 1985 : 122f.). According to Neubert text types are as heterogenous as the social acts of their users. They incorporate the latter's mutual knowledge geared to a particular set of social activities. They motivate particular frames and act out certain scenarios. Their profile makes it possible for the participant to focus his attention on just that part of the social process for which the text type is functioning as mediator. Text types recast the linguistic material available in the system of a language into socially efficient, effective and appropriate moulds. (For the above cf. Neubert $1985: 124 f$.)

Thus - according to Neubert - texts are variant instances clustering around a holistic experience that has been shared over a time. This "prolonged interactive experience" takes the character of prototypical encounters and this empirical prototypicality is then translated into the concept of the prototype text. Its essential nature lies in the fact that it is more than the sum of its features. What has hitherto been called textual features does not stand in an all-or-nothing relationship to the prototype text. Features, which may be counted for or, at least, listed for individual texts, i.e. the text instances, can never fully define the prototype. It is a historically and socially conditioned mode of organising knowledge in spoken or written discourse. Text types are prototypes according to just this definition. (For the above cf. Neubert $1985: 127$.) Thus prototypical analysis takes up the often very intuitive conceptualisations of text typology and subjects them to a much more rigorous and realistic treatment in the face of the complex, but certainly not utter irregular nature of concrete textual instances (Neubert 1985 : 131).

Prototypical analysis might therefore also be suggested for classifying and categorising the various types of translation. One of the translation scholars that has recently taken this approach in a practice-oriented way is M. Snell-Hornby (1986). She suggests a translation-oriented text-typological approach, where prototypologies are to take the place of traditional typologies that do not aim at division, but rather at focussing, and therefore permits for fuzzy edges and mixed types. She presents a spectrum reaching from literary translation (literarisches Übersetzen) via common-language translation (gemeinsprachliches Übersetzen) to sci-tech translation (Fachïbersetzen).

For the purposes of our Symposium we follow this division - which is in a way a classical one - adding another distinctive feature : the mode of presentation and reception of a translated text, i.e. the distinction between oral and written translation. While 
the first three papers present studies of written translation, i.e. the translation of technical texts, literary translation, and written translations performed in the foreignlanguage classroom, the remaining papers deal with oral translation, ranging from oral translation in typical communication situations in the Australian context to the most sophisticated form of oral translation - conference interpretation.

The first paper by Reiner Arntz (University of Hildesheim, FRG) discusses steps towards the development of a translation-oriented typology of technical texts, at the same time also integrating "contrastive textology" in these attempts. He concludes by suggesting several fields of application for such a translation- oriented typology of technical texts : the training of translators, terminology science and machine translation.

Ortrun Zuber-Skerritt (Griffith University, AUS) in her paper takes up problems of literary translation. As a specialist in drama translation science, she endeavours to arrive at a typology of translation which deals with both the translation of drama from one language and culture into another and with the various aspects of transposing the dramatic scripts onto the stage or, vice-versa, the creation of drama through processes of theatre production.

In her paper dealing with forms of written translation in the foreign-language classroom, Marieke Van Willigen-Sinemus (University of Utrecht, The Netherlands) discusses translating in the classroom as opposed to other forms of translation, notably translating for professional purposes. As an expert in foreign-language didactics she concerns herself specifically with translations from $\mathrm{L} 1$ into $\mathrm{L} 2$, i.e. from mother tongue into the foreign language, made in the classroom, considering these translations as autonomous texts in $\mathrm{L} 2$.

In the first paper dealing with oral translation, Adolfo Gentile (Victoria College, AUS) attempts to make a contribution to the typology debate by looking at oral translation in the Australian context and outlining characteristics of that context which sets it apart from others. His observations are discussed within a theoretical framework for the development of text typologies that range from function-oriented to transfermethod-oriented typologies.

Last but not least, Henry Niedzielski (University of Hawaii, Honolulu, USA) in his paper proposes a pioneering typology of texts encountered in the work-load of conference interpreters, which should stimulate further research. He is also making valuable suggestions for the practice and the teaching of interpretation.

HILDEGUND BÜHLER

University of Vienna, Austria

BIBLIOGRAPHY

BEAUGRANDE, R.-A. de and W.U. DRESSLER (1986) : Introduction to Text Linguistics, London, Longmans.

NEUBERT, A. (1985) : Text and Translation, Leipzig, Verlag Enzyklopädie.

SNELL-HORNBY, Mary (ed.) (1986) : Übersetzungswissenschaft. Eine Neuorientierung, Tübingen, Francke. 